\title{
Isha-Upanishad and Economics Consideration: An Elucidation
}

\author{
Babu Ram Gewali, Ph. D.*
}

\begin{abstract}
In this article, the effort has been made to trace the tradition of oriental economic thoughts-spread in the four Vedas and Upanishad, which are the earliest documents of human civilization. For the analysis the first Upanishad-Isha has been selected. This analysis is based on the first mantra of Isha-Upanishad. It is concluded that the first serious econic thinking was inisitated by the composer of Upanishad.
\end{abstract}

\section{INTRODUCTION}

Upanishads are the earliest philosophical texts of human civilization. These are extracts from Vedas. The composition of these Upanishads is impersonal and therefore the authors of these texts are unknown. The method of Upanishads is dialogue method which was also used by Plato in Greek. The first Upanishads were composed during pre Buddhist era. Although the total number of Upanishads is said to be 1180 but some 200 texts are known. Of them 108 texts are available. The first dozen of texts are known as principal texts because these texts were explained by Shankaracharya at first. (Apurvananda, 2010, 30n) Although the first Persian translation was done by Akabar but this translation is not found. Darashikoha, the elder brother of Moghul emperor Aurangzeba translated 50 Upanishads into Persian directly from Sanskrit in 1657 CE with the help of Kashamiri Pandits. After 100 years of the Persian translation, one of them, Katha-Upanishad was translated into French and Latin but only Latin portion was published. Although the first English translation was done by Raja Rammohan Roy (1830-1890 CE) yet the first well known English translation was done by Swami Parmananda- a disciple of Swami Ramakrishna in 1909 for British devotees. He translated four Upanishads- Isha, Katha, Kena, and Mundaka. Swami Vivekananda also preached on various topics of Upanishad in UK and USA. Max-Muller also presented translation of Upanishads in 1920 CE. Sir Edwin Arnold's commentary on Katha-Upanishad the Secret of Death made it more popular. Nepalese translations were presented by NRPP in 1977 CE.

Most voluminous Upanishad is Brihadaranayak and smallest one is Mandukya. Isha is one of the principle Upanishads and is associated with Yajur-Veda. This is also known as the first of the Upanishads. The title of this Upanishad- Isha is based on the first word of the first mantra of the Upanishad.

\section{ECONOMIC CONSIDERATIONS IN ISHA-UPANISHAD}

The Isha-Upanishad has the discussion on economics. The first mantra is as follows-

ईशावास्यमिदं सर्व यत्किंच जगत्यां जगत् ।

तेन त्यत्तेन भुग्जीथा मा कस्यस्वित् धनम् ।19।।

\footnotetext{
* Dr. Gewali is Professor of Economics, Butwal Multiple Campus, T.U., Butwal.
} 
[Ishavasyamidam sarvam yatkimcha jagtyam jagata

Tena tyaktena bhunjitha ma gridhah kasyaswit shanam.] (Isha-Upanishad, 1)

Meaning of the words in the mantra is as follows:

jagatyam- within the universe

yat-kim-cha-whatever (is there)

jagat-all that is animate and inanimate

idam- this,

sarvam- all of them,

Isha- the power of Nature, Lord,

avasyam- controlled, managed, provided,

tena- by Him, so that

tyaktena- set apart quota, economize, do not hoard for yourself only

bhunttha- accept, consume or get satisfaction by them,

ma- do not

gridhah- greed

dhanam- the wealth, goods used to satisfy human wants

kasya swit- Whose (wealth)? What (wealth)?

\section{Translation}

Within the universe, every living and non living thing is managed by the nature (the power of Lord is hidden in all the things of the universe). One should consume things, which are set aside as his quota, because things are assigned to all (Economize the resource. who is the owner of natural resource?). It is to be noted that in the beginning the meaning of this word was knowledge or wealth. (Bokare, 2009, 88) Tena Tyaktena bhunjitha may be translated as- he, who sacrifices, really consumes. Whatever the translations be, the main points of this mantra are as follows.

- $\quad$ All kinds of resources are natural wealth

- $\quad$ Economize wealth for the sake of others

- Don't be greedy for the other's wealth

- Whose wealth? What's wealth?

\section{Elucidation}

The economic issues raised in this mantra can be explained as follows-

\section{All the Resources are Natural Wealth}

All the textbooks of economics accept that all the natural things are free resources available to mankind. In the words of Prof. Marshall- Whole of the materials and forces which nature gives freely for man's aid in land and water in air and light and heat are natural resources. In other words natural resources aresurface of the earth, water bodies like rivers, lakes and animals in it, minerals, forests and animals in it, energy source like water, wind, solar energy, sea coast, natural harbor and animals and plants in it, and rainfall etc. 
Isha-Upanishad and Economics Consideration..../37

Two things are to be worth noting for being natural gift- a) All the things above or below the earth's surface are natural wealth, such as natural air, sunshine, mineral deposits, ground water, and rocks; b) Only those things are natural wealth which are within the reach of mankind and therefore they are within the potential consumption. The materials and powers beyond the human reach are not natural wealth, for example mineral deposits in the moon are not natural wealth but when they become reachable they will become land.

On the basis of this logic land locked countries are claiming their natural right on sea and sea coast. Despite of this fact UNO is unable to provide this right to underdeveloped land locked countries. If all the natural resources are natural wealth and everybody has the equal right to utilize it, then there will be no land locked country in the world. Isha-Upanishad also supports the claim of land locked countries and their demand for free and easy approach to sea port- the international wealth.

Upanishads classify all the natural wealth in two parts- external wealth and internal wealth. Land, water, heat, air, and space are called external natural wealths, whereas, skill, determination, and intellect are internal natural wealths. (Srimad Bhagvadgita 7.4-5) Modern Human Resource Theorists have now started to think over the theory of Upnishads that internal powers are also natural wealth.

\section{Optimum use of Natural Resources}

Since natural wealths are free, therefore it is the duty of all the persons to respect these wealths and avoid their misuse. The misuse of resources leads the society to the calamities. Environmental pollution is the consequence of the misuse of the natural resource. The respect of natural resource can be done by economizing it- that is, getting maximum satisfaction from the use of minimum quantity. Economizing resources denotes maximum production from the use of given scarce resources. Economizing resources also denotes that present society is utilizing the wealth for getting satisfaction at present and at the same time providing guarantee of the wealth for the use of future generation. This is a fact of eco-system and natural balance for ever. Economization and co-operation is the method of best use and respect of natural resources.

Without the feelings of sacrifice no one can economize the resources. One more thing is to be noted is that only that person can get perfect satisfaction who is ready to sacrifice for others. A selfish person cannot get maximum satisfaction. If the neighbor is hungry, civilized person couldn't get satisfaction from sweetest meal of the earth. The mercantilist theory- let my neighbor be poor was failed due to this selfish feeling. Now, economists have concluded that rich countries cannot be happy unless their poor neighbours are spending a prosperous life.

\section{Consumption of Unearned Wealth is prohibited}

The circle of one economic activity is completed after the consumption. Want (or the desire of consumption) is the starting point of an economic activity. To satisfy want the wealth (means or goods/services) is earned. With the help of wealth the want is satisfied. The satisfaction of a want is known as consumption. This complete circle is known as economic activity. Since spending in the society depends on one's earning, therefore social acceptability should be a fundamental feature of earning. An earning becomes socially acceptable when one's earning (and expenditure) does not reduce 
the consumption capacity of other. If the earning (and consumption) is done in the way that it increases the satisfaction of all the members of society, it is known as the best way of consumption or, otherwise, increases the satisfaction of at least one without reducing the satisfaction of all others.

Rents and monopoly profits are unearned income and therefore criticized by the socialist thinkers. In $19^{\text {th }}$ century Sir Sidney Webb and Mrs. Beatrice Webb, on the basis the unearned theory, argued that the rent on land is the root cause of all social evils and economic inequalities. Unearned income means the earner is one person and the user is the other. Isha- Upanishad prohibits the use of unearned wealth (or other's wealth) to get satisfaction. The Rig-Veda goes even farther and says that the person, who consumes an unearned income, is a thief.

\section{Who is assigned the Owner of Wealth?}

Swit means assigned therefore kasya swit dhanam means who has been assigned the owner of wealth? In other words it means whose wealth? What's wealth? This is yet to be determined issue.

The question of ownership of income is the issue of input pricing in Economics. Modern economists are trying to find the best answer since the time of Francis Quesney.

Theories of distribution are trying to find the exact answer of this question. There are many distribution theories in economics- theory of rent, standard of living theory of wages, demand and supply theory of interest, risk theory of profit. All are agree that each of the factors is partly owner of the wealth but their views are divided on the question of the share of the ownership.

All the theories have been criticized on one or more grounds. Most satisfactory theory of distributionownership of wealth, has been propounded recently by the economists now is marginal theory of distribution. According to this theory every factor of production is owner of that part of wealth which was contributed by it, known as marginal production. But it is very difficult to find actual contribution of each of the factor. We can not separate the actual production of labour and capital. Economists agree that all the factors are jointly owner of the wealth. Thus the wealth is for all. This conclusion is similar to the saying of Isha-Upanishad.

\section{CONCLUSION}

Adam Smith's pioneering academic exercise has the title 'An Enquiry into the Nature and Causes of Wealth of Nations', it is so close to the suggested enquiry on wealth in Isha-Upanishad. The first mantra of Isha-Upanishad has raised some fundamental questions of economics discussed in the modern text books- natural resources and their economizing use, use of earned wealth with socially accepted methods, and the problem of ownership of wealth. If we consider these issues, economists would agree that these are central issues of modern economics. Thus, it can be concluded that the first serious economic thinking was done by the composer of Isha-Upanishad in the history of economic thought. 
Isha-Upanishad and Economics Consideration.... /39

\section{REFERENCES}

Anikin, A. (1975). A Science in its Youth, Moscow: Progress Publishers.

Apurvananda, (2010). Shankaracharyako jivani (Biography of Shankaracharya), translation with explanatory notes by B. R. Gewali, Kathmandu: Vidyarthi Prakashan.

Bokare, M. G. (2009). Hindu economics, Pune: MG Bokare Memorial Memorial Foundation.

Jayaswal, KP. (1978).Hindu polity, Bangalore: The Bangalore Printing and Publishing Company Ltd.

Kane, PV. (1941). History of Dharmashastra Part 1, Puna: Bhandarkar Oriental Institute. Accessed from www.archive.org/.../historyofdharmashastras029210mbp.

Nayak, Purusottam.(1997).“Origin of the science of Economics- a quest”, Journal of Assam University, vol. 2, 1997. Accessed from www.citeseerx.ist.psu.edu/viewdoc/summary?

Panthi, Tikaram.(2008).Sanskritik Samvikshana (An investigation of culture), Butwal: Vishva Hindu Mahasamgha, Rupandehi.

Rangaswami Aiyangar, KV.(1965). Aspects of Ancient Indian Economic Thought. Banaras: Banaras Hindu University.

Samuelson, P.A. and W.D.Nordhaus (2002).Economics, Washington: McGraw Hill.

Sen, Amartya (1993).On Ethics and Economics, UK: Oxford University press.

Srimadbhagvadgita-as it is.(1980). illustrator Sri La Prabhupada, International Society for Krishna Conscienceness : Bhaktivedant Book Trust.

Vaishya, M. C. (1972). Arthik Vicharo Ka Itihasa (History of Economic Ideas), Agra : Ratan Prakashan Mandir. 